\title{
Estuary hydrogeomorphology affects carbon sources supporting aquatic consumers within and among ecological guilds
}

\author{
D. J. Hoeinghaus $\cdot$ J. P. Vieira $\cdot$ C. S. Costa $\cdot$ \\ C. E. Bemvenuti $\cdot$ K. O. Winemiller • \\ A. M. Garcia
}

Received: 28 December 2010/Revised: 19 April 2011/Accepted: 7 May 2011/Published online: 26 May 2011

(C) Springer Science+Business Media B.V. 2011

\begin{abstract}
The relative importance of carbon sources supporting aquatic food webs within and among estuaries may be influenced by factors that affect relative availability of autotrophic carbon sources, as well as movement of individuals among marine, estuarine and freshwater zones. We used stable isotopes of carbon and nitrogen to examine (1) the relative importance of carbon sources supporting estuarine consumers among estuaries with different hydrogeomorphic characteristics, (2) stable isotope signatures of consumer ecological guilds defined by dependence on estuarine habitats and residence time, and (3) if patterns in stable isotope signatures of ecological guilds repeat across estuaries with distinct hydrogeomorphological features. At the assemblage
\end{abstract}

Handling editor: M. Power

K. O. Winemiller

Section of Ecology and Evolutionary Biology,

Department of Wildlife and Fisheries Sciences, Texas

A\&M University, College Station, TX 77843-2258, USA

D. J. Hoeinghaus

Department of Biological Sciences, Institute of Applied

Sciences, University of North Texas, 1155 Union Circle

\#310559, Denton, TX 76203-5017, USA

J. P. Vieira - C. S. Costa - C. E. Bemvenuti ·

A. M. Garcia $(\bowtie)$

Instituto de Oceanografia, Universidade Federal de Rio

Grande-FURG, Rio Grande, RS CP 474, Brazil

e-mail: amgarcia@mikrus.com.br level, consumer carbon isotope signatures reflected the consumption of locally abundant primary production sources and differed across estuary types (choked lagoon, coastal river). Consumer ecological guilds differed in $\delta^{13} \mathrm{C}$ within sites, and the same trend repeated across sites but with differing magnitudes. This variation is attributed to movement and residence patterns in addition to differences in the relative abundances of autotrophic sources across sites. Although within-estuary variation in consumer resource use is to be expected, estuarine food webs may be broadly classified according to landscapescale hydrogeomorphic factors that allow an initial prediction of the relative importance of carbon sources to secondary production. Predictions may be refined at the species level using knowledge of habitat use and residence time. Such predictions are useful as a starting point for poorly studied regions such as ours in southern Brazil, as well as for globalscale analyses of patterns in estuarine food webs.

Keywords Brazil · Food web - Migration - Salt marsh · South America - Subsidies

\section{Introduction}

Estuaries are spatially complex, formed by forces of freshwater inflow meeting marine water across narrow to broad areas, and may vary greatly in physicochemical conditions due to tidal flux and 
season. Patterns of dominance of primary producers often change along estuarine gradients (Day et al., 1989; Kennish, 1990; Isacch et al., 2006), such as in a gradient of marsh grasses or mangroves occupying relatively higher elevations or the inter-tidal zone and seagrass and algae occurring in lower elevations. Corresponding with such changes in dominance of primary producers, prior food web studies have shown that the relative importance of autotrophic carbon sources supporting secondary production of aquatic consumers often changes along gradients within estuaries (Peterson et al., 1985; Deegan \& Garritt, 1997; Garcia et al., 2007; Kanaya et al., 2007).

Estuarine food web studies have identified similarities as well as differences in the relative importance of autotrophic production to consumers (e.g., Hsieh et al., 2002; Kang et al., 2003; Winemiller et al., 2007; Rodriguez-Grana et al., 2008). Similar hydrogeomorphic factors that drive patterns of spatial variation within estuaries should also result in variation among estuaries with different characteristics. For example, tidal creeks, lagoons and bays vary greatly in their relative proportion of littoral to open water area, and may also vary in the relative size of the estuarine zone in general. Based on findings from inland freshwater ecosystems where landscape-scale hydrogeomorphic features have a strong influence on food web structure and carbon flow (Hoeinghaus et al., 2007, 2008), we expect differences in the relative importance of carbon sources among estuaries to correspond to hydrogeomorphic characteristics that affect patterns of dominance of primary producers.

Patterns of carbon flow in estuarine food webs may also be affected by the movement of individuals among marine, estuarine, and freshwater zones. Local estuarine food webs may receive subsidies of marine and freshwater production via marine and freshwater visitant species that serve as transport vectors (e.g., Deegan, 1993; Garman and Macko, 1998; MacAvoy et al., 2000) or by direct flux in the environment (e.g., Connolly et al., 2005). Isotopic differences in source signatures among freshwater, estuarine, and marine systems may be retained to certain degrees in nonresident individuals (dependent on length of time since arriving, body size, feeding rate, e.g., Rubenstein \& Hobson, 2004; Bardonnet \& Riera, 2005; Herzka, 2005) or assimilated by resident estuarine species through trophic interactions. For example, in previous research in this region of South America, stable isotope signatures of carbon were useful to identify movement of individuals from freshwater into estuarine zones within a large coastal lagoon (Garcia et al., 2007). In this manner, the functional composition of the estuarine consumer assemblage, specifically the relative composition of estuarine resident and visitant species, may affect the relative importance of carbon sources identified at the assemblage level and also may be expected to vary among functional groups.

In this study, we used stable isotopes of carbon and nitrogen to examine food web structure of three estuaries of subtropical Brazil. This study provides new data on an understudied region, and further investigates underlying drivers of structure in estuarine food webs in general. We were interested in whether the relative importance of carbon sources supporting estuarine consumers differed among estuaries with different hydrogeomorphic characteristics, and to what extent functional roles had an effect on consumer resource use and isotopic signature. Specifically, we ask the following questions: (1) within estuaries, do consumer ecological guilds defined by dependence on estuarine habitats and their time of residence differ in their carbon isotope signatures?, and (2) do patterns in carbon isotope signatures of ecological guilds within an estuary repeat in a similar manner across estuaries situated in the same coastal plain but with distinct hydrogeomorphological features?

\section{Materials and methods}

Regional description and study sites

Estuarine food webs were investigated at three locations along the southern Brazilian coast (Fig. 1). Hydrogeomorphologic characteristics differ among the estuaries (Table 1), primarily being classified as "choked lagoons" (sensu Kjerfve, 1986; Tramandaí-Armazén lagoon complex and Patos Lagoon, although Patos Lagoon is far larger than the Tramandaí-Armazén lagoon complex) and a coastal river (Chuí). The studied estuaries are located in Rio Grande do Sul (RS), the southernmost state of Brazil, across a $500 \mathrm{~km}$ stretch of coastline from the northern-most site (Tramandaí, $30^{\circ} \mathrm{S}, 50^{\circ} \mathrm{W}$ ) to the Brazil-Uruguay border (Chuí, $33^{\circ} \mathrm{S}, 53^{\circ} \mathrm{W}$; Fig. 1). 
Fig. 1 Map of South America, with detail of the Rio Grande do Sul, Brazil, coastline depicting the location and spatial structure of Tramandaí, Patos Lagoon and Chuí estuaries. Shading in inset maps for each site indicate saltmarsh area

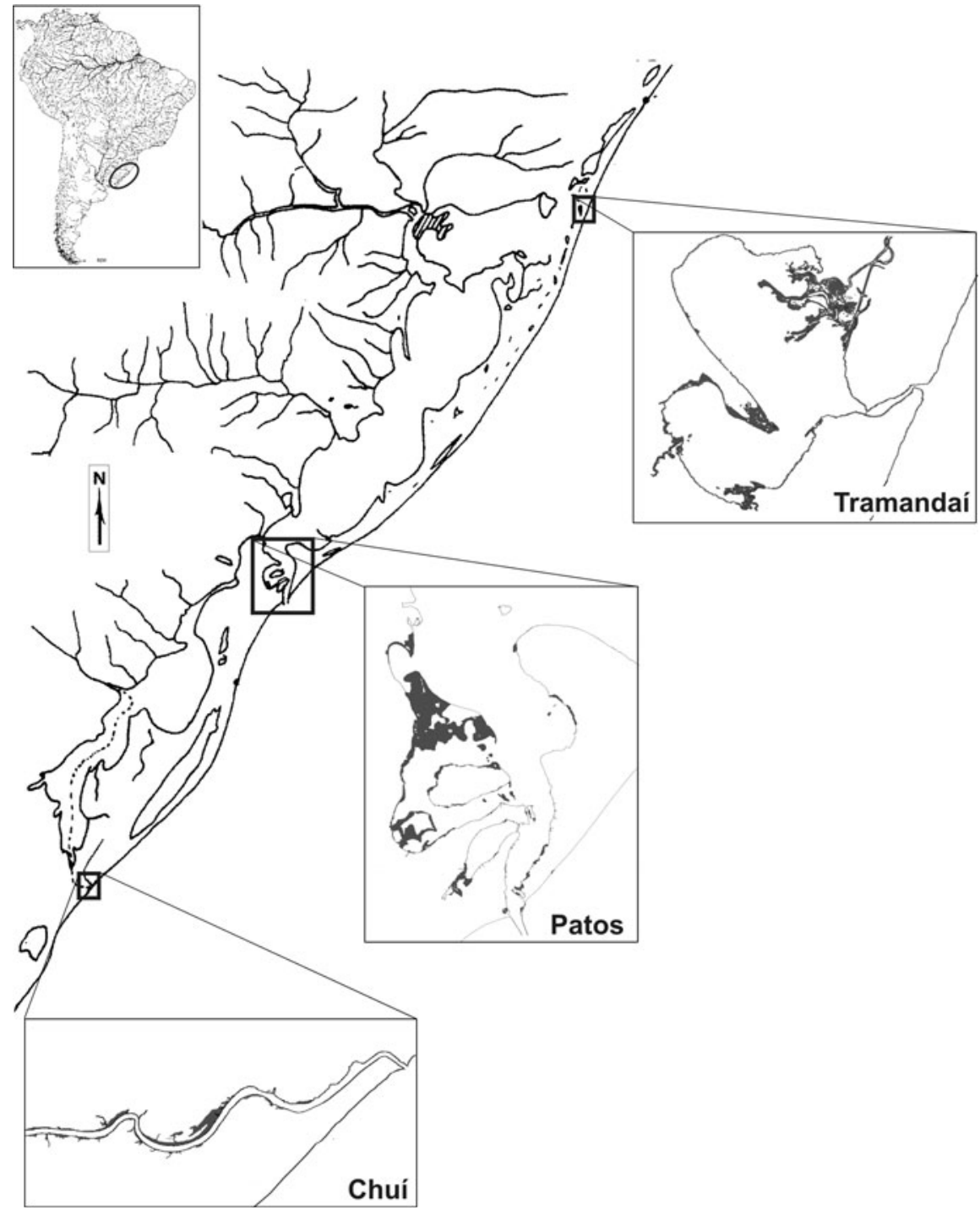

This coastal zone is influenced by the convergence of oligotrophic and nutrient-rich subtropical waters of the Brazil and Malvinas currents, respectively, as well as large amounts of continental freshwater inflow into the coastal zone from the La Plata River and Patos-Mirim lagoon complex. These unique conditions make this area one of the most productive in the southwestern Atlantic (Seeliger et al., 1996).

The Tramandaí-Armazém lagoon complex (hereafter Tramandaí) has an area of $30 \mathrm{~km}^{2}$. Its main tributaries are a river draining highland areas and several lakes, which together comprise a drainage basin of 2,697 $\mathrm{km}^{2}$. The estuarine zone is restricted to Armazém lagoon and the area near the connection with the sea, which is $1.5 \mathrm{~km}$ long, $0.3 \mathrm{~km}$ wide, with depths ranging from $1.5 \mathrm{~m}$ in the shallow waters and $5 \mathrm{~m}$ in the main channel (Fig. 1). Strong variations in its environmental conditions over short time periods and throughout the year usually occur due to sudden changes in wind patterns. Salinity is influenced by changes in tides and freshwater inflow (Schwarzbold \& Schäfer, 1984).

Patos Lagoon is the better studied of the three estuarine systems (Seeliger et al., 1996; Seeliger, 2001). The lagoon is $250 \mathrm{~km}$ long and $60 \mathrm{~km}$ wide, which gradually narrows into a channel (700 m wide) connected with the sea (Fig. 1). The estuarine zone is restricted to its southern region and comprises 
Table 1 Hydrogeomorphic and vegetation characteristics of Tramandaí, Patos Lagoon, and Chuí estuaries

\begin{tabular}{|c|c|c|c|}
\hline \multirow[t]{2}{*}{ Features } & \multicolumn{3}{|l|}{ Estuary } \\
\hline & Tramandaí & Patos Lagoon & Chuí \\
\hline Drainage basin $\left(\mathrm{km}^{2}\right)$ & 2,698 & 201,626 & 276 \\
\hline Surface area $\left(\mathrm{km}^{2}\right)$ & 30 & 10,360 & 18 \\
\hline Area mixohaline zone $\left(\mathrm{km}^{2}\right)$ & $19.4^{\mathrm{a}}$ & 971 & 0.3 \\
\hline Area mixohaline zone/surface area $(\%)$ & 64.6 & 9.37 & 1.67 \\
\hline Saltmarsh longitudinal distribution $(\mathrm{km})^{\mathrm{b}}$ & 7.7 & 42.5 & 4.5 \\
\hline Saltmarsh spatial coverage $(\text { ha })^{c}$ & 92.4 & $6,837.5$ & 7.5 \\
\hline Mean depth (m) & 1.5 & 5.0 & 2.0 \\
\hline Maximum depth (m) & 5.0 & 18.0 & 3.0 \\
\hline Salinity (mean) & 3.6 & 9.6 & 3.3 \\
\hline Water transparency $(\mathrm{cm})$ & 34.4 & 39.6 & 25.0 \\
\hline
\end{tabular}

approximately $10 \%$ of the entire lagoon $\left(976 \mathrm{~km}^{2}\right)$. Apart from a deeper navigation channel, about $80 \%$ of the estuarine zone is less than $2 \mathrm{~m}$ deep. Tidal influence in the estuary is minimal (mean tidal amplitude is $0.47 \mathrm{~m}$ ). Wind and seasonal pulses of freshwater inflow influence longitudinal and vertical patterns of water circulation and salinity (Seeliger et al., 1996), and have strong effects on the spatiotemporal dynamics of the fish assemblages (Garcia et al., 2004). The lagoon has a large drainage basin $\left(201,626 \mathrm{~km}^{2}\right)$ formed by rivers characterized by a mid-latitude flow regime: high discharge in late winter and early spring and low to moderate discharge through summer and autumn (Moller et al., 2001). There is great habitat heterogeneity within the estuary, particularly associated with $\mathrm{C}_{4}$ plants such as widgeon grass (Ruppia maritima), which forms extensive meadows during spring and summer (Costa et al., 1997), and saltmarsh plants such as Spartina densiflora and Spartina alterniflora that occur in higher and lower saltmarsh elevations, respectively (Costa et al., 1997). These vegetated habitats provide nursery grounds for several marine fishes and shrimp species (Garcia et al., 1996; Garcia \& Vieira, 1997; Costa et al., 1997), which are abundant in the lagoon and sustain an artisanal fishery that provides livelihood for $\sim 3,500$ fishermen (Vieira \& Castello, 1996; Reis \& D'incao, 2000).
In contrast with the other two choked lagoon estuaries, Chuí is formed by a $60 \mathrm{~km}$ river that empties into the sea through a narrow channel just $60 \mathrm{~m}$ wide (Fig. 1). Depth ranges from 1.5 to $3 \mathrm{~m}$, and the small estuarine zone (only $0.3 \mathrm{~km}^{2}$ ) extends $\sim 1 \mathrm{~km}$ up-river and with more prevalence of oligohaline conditions in comparison with the other two estuaries (Pereira et al., 1998). This site, therefore, has less diversity of typical estuarine vegetated habitats (seagrass meadows and saltmarshes) that are commonly found in the other estuaries, especially at Patos Lagoon. Rather, the dominant vegetated habitats along its margins are the $\mathrm{C}_{3}$ plants Scirpus olneyi and Juncus acutus in the lower and higher elevations, respectively (C. S. Costa, unpublished data).

Vegetation surveys, and field collection and sample processing for isotopic analyses

Patterns of dominance were characterized for vegetation at each estuary from satellite images and field surveys (Table 2). High resolution digital aerial photographs (for Patos Lagoon) and QuickBird-2 satellite images (Tramandaí and Chuí) were classified by supervised pixel-based algorithm (maximum likelihood classification, MAXVER) and used to generate land cover thematic maps of the marginal salt marshes. In each estuary, image classifications, cover 
Table 2 Patterns of dominance (spatial coverage) and carbon stable isotope values for the representative vegetation at each site

\begin{tabular}{|c|c|c|c|c|}
\hline & Tramandaí & Patos Lagoon & Chuí & Mean $\delta^{13} \mathrm{C}$ \\
\hline \multicolumn{5}{|l|}{ Marsh vegetation } \\
\hline Cyperus spp $\left(\mathrm{C}_{3}\right)$ & Sparse & Rare & Rare & -28.0 \\
\hline Juncus spp. $\left(\mathrm{C}_{3}\right)$ & Sparse & Abundant & Abundant & -27.0 \\
\hline Panicum elephantipes $\left(\mathrm{C}_{4}\right)$ & Sparse & - & - & \\
\hline Paspalum vaginatum $\left(\mathrm{C}_{4}\right)$ & Sparse & Rare & Sparse & -12.5 \\
\hline Salicornia gaudichaudiana $\left(\mathrm{C}_{3}\right)$ & Rare & Rare & Sparse & -29.7 \\
\hline Scirpus californicus $\left(\mathrm{C}_{3}\right)$ & Sparse & Rare & Rare & -26.1 \\
\hline Scirpus maritimus $\left(\mathrm{C}_{3}\right)$ & Rare & Sparse & - & -27.0 \\
\hline Scirpus olneyi $\left(\mathrm{C}_{3}\right)$ & Abundant & Sparse & Abundant & -28.5 \\
\hline Spartina alterniflora $\left(\mathrm{C}_{4}\right)$ & - & Abundant & - & -11.4 \\
\hline Spartina densiflora $\left(\mathrm{C}_{4}\right)$ & Rare & Abundant & Sparse & -12.2 \\
\hline \multicolumn{5}{|l|}{ Submerged aquatic vegetation } \\
\hline Ruppia maritima $\left(\mathrm{C}_{4}\right)$ & Abundant & Abundant & - & -11.8 \\
\hline Enteromorpha sp. $\left(\mathrm{C}_{4}\right)$ & Abundant & Sparse & - & -12.9 \\
\hline
\end{tabular}

Marsh vegetation abundance based estimates of species cover in percents: rare $0.1 \leq x \%<4.0$; sparse $4.0 \leq x \%<16.0$; abundant $x \% \geq 16.0$. Submerged aquatic vegetation abundance is from Costa et al. (1997) and Rosa-Filho et al. (2004). Mean $\delta^{13} \mathrm{C}$ values from this study, Garcia et al. (2007), and Abreu et al. (2006)

maps and salt marsh area were estimated using GIS SPRING software (Camara et al., 1996). During the extensive ground verification, ocular estimates of percent cover by species were recorded in 57,585 , and 65 quadrads $\left(0.25 \mathrm{~m}^{2}\right)$ along transects perpendicular to the estuarine margins of Tramandaí, Patos Lagoon, and Chuí estuaries, respectively. The percentage cover occupied by each species was used to calculate mean cover value that was assigned to an abundance class, based on an octave scale (logarithmic to the base 2; Gauch, 1984), as follows: rare $0.1 \leq x \%<4.0 ;$ sparce $4.0 \leq x \%<16.0$; abundant $x \% \geq 16.0$.

Fishes, macroinvertebrates and primary producers were sampled at several points in each estuary during a 1 week period of November 2004 (late austral spring). Late spring is an important season for these ecosystems because of high primary production and the presence of diverse guilds of consumers (see below). Fishes were collected using multiple gears (beach seines, cast nets and gillnets) to collect representative samples of the fish diversity at each site. Benthic macroinvertebrates and infauna were collected using cores, and some larger invertebrate species (e.g., Callinectes sapidus) were also collected using seines. Dominant floating and emergent macrophytes were collected by hand. Our $\delta^{13} \mathrm{C}$ data for plants (including some previously published by
Garcia et al., 2007) was complemented with information reported by Abreu et al. (2006) for Patos Lagoon (Table 2).

All samples were placed on ice for transport to the laboratory where they were stored frozen, and later processed following standard procedures for isotopic analyses (Garcia et al., 2007, Hoeinghaus \& Davis, 2007). Briefly, samples consisted of several leaves for plant species, $\sim 5 \mathrm{~g}$ of pure muscle tissue from individual fish and large invertebrates. In the case of smallest size-classes $(<50 \mathrm{~mm}$ total length for fishes, $<100 \mathrm{~mm}$ carapace width for crabs) and taxa (shrimp, bivalves, and polychaetes), a composite sample of individuals of approximately the same size was taken by combining pure muscle tissue from 5-15 individuals from the same site. Because isotopic signatures of crustacean exoskeletons reflect assimilated calcium carbonate derived from the environment, only pure muscle samples were used for stable isotope analysis. Pure muscle tissue was dissected from crabs and shrimp using a sterile scalpel. For bivalves, the adductor was removed and processed in the same manner. Polychaetes were processed whole. Thawed samples were carefully inspected to remove non-muscle matter (e.g., bone or scales in fish tissue), rinsed with distilled water, placed in sterile Petri dishes, and dried in an oven at $60^{\circ} \mathrm{C}$ to constant weight (minimum of $48 \mathrm{~h}$ ). Dried samples were 
ground to a fine powder with a mortar and pestle and stored in clean glass vials.

Sub-samples were weighed to the nearest $0.01 \mathrm{mg}$, and pressed into Ultra-Pure tin capsules (Costech Analytical, Valencia, California), and sent to the Analytical Chemistry Laboratory of the Institute of Ecology, University of Georgia, for analysis of carbon and nitrogen isotope ratios. Results are expressed in delta notation (parts per thousand deviation from a standard material): $\delta^{13} \mathrm{C}$ or $\delta^{15} \mathrm{~N}=\left[\left(R_{\text {sample }} / R_{\text {standard }}\right)-1\right] * 1000$, where $R=$ ${ }^{13} \mathrm{C} /{ }^{12} \mathrm{C}$ or ${ }^{15} \mathrm{~N} /{ }^{14} \mathrm{~N}$. The standard material for carbon is Pee Dee Belemnite (PDB) limestone, and the nitrogen standard is atmospheric nitrogen. Standard deviations of $\delta^{13} \mathrm{C}$ and $\delta^{15} \mathrm{~N}$ replicate analyses $(n=18$, each) were 0.14 and $0.13 \%$, respectively.

Data analysis

Subsequent analyses are based on carbon and nitrogen isotopic ratios of 140 consumer samples (Tramandaí: $n=36$; Patos: $n=71$; Chuí: $n=33$ ). Individuals of some large-bodied fish species were separated into size classes to reduce potential bias due to ontogenetic diet shifts. Bi-plots of $\delta^{15} \mathrm{~N}$ and $\delta^{13} \mathrm{C}$ values of fishes and macroinvertebrates were used to visualize patterns of isotopic variation across sites. The relative importance of various sources of organic carbon assimilated by consumers is indexed by relative positions of consumers on the $x$-axis $\left(\delta^{13} \mathrm{C}\right.$ values), whereas trophic position is indicated by relative position on the $y$-axis $\left(\delta^{15} \mathrm{~N}\right)$ (Peterson \& Fry, 1987). Analysis of variance (ANOVA) was used to compare $\delta^{13} \mathrm{C}$ and $\delta^{15} \mathrm{~N}$ of fish and invertebrate consumer assemblages among sites. Within each site, ANOVA was used to compare consumer $\delta^{13} \mathrm{C}$ among four ecological guilds identified by Garcia et al. (2003): (1) estuarine residents-species typically occurring and breeding within the estuary; (2) estuarine dependents-marine or freshwater spawning species found in large numbers within the estuary during certain periods of their life cycle; (3) marine vagrants-species typically inhabiting marine habitats and rarely occurring within the estuary; and (4) freshwater vagrants-species typically inhabiting freshwater habitats and rarely occurring within the estuary. When a significant main effect was observed, pairwise comparisons of site or guild means were performed using Tukey's post-hoc procedure. For post-hoc analyses of guild means at
Chuí and Tramandaí, the marine vagrant guild was excluded because it was represented by only a single species at both sites.

\section{Results}

Between 46 and $76 \%$ of the mean plant cover of the salt marshes was accounted for by five or fewer species, and dominant plants were not the same among estuaries (Table 2). The South American cordgrass $S$. densiflora was the most abundant species in the mesohaline Patos Lagoon estuary, whereas $S$. olneyi occurred in dense stands in low marshes of the oligohaline estuaries of Chuí and Tramandaí. Salt marsh areas of Tramandaí and Patos Lagoon were 10 and 100 times larger than Chuí, respectively. The choked lagoons also showed extensive beds of widgeon grass Ruppia maritima and macroalgae Enteromorpha spp. (especially Tramandaí), more diversified salt marsh flora and site specific $\mathrm{C}_{4}$ plants such as S. alterniflora (low marshes of Patos Lagoon) and Panicum elephantipes (marsh-land border of Tramandaí) (Table 2).

A total of 31 fish species and 8 invertebrate species was collected across the three sites (Table 3). A similar number of fish and invertebrate species were collected at Patos Lagoon (19 fish species and 5 invertebrate species) and Chuí (20 fish species and 3 invertebrate species), whereas fewer species were collected at Tramandaí (7 fish species, 5 invertebrate species; Table 3). Species representing all four ecological guilds were collected at Patos and Chuí (Table 3), although freshwater vagrant species dominated Chuí (17 species) and estuarine resident and estuarine-dependent species dominated Patos Lagoon (12 and 9 species, respectively). Aside from the marine vagrant Pomatomus saltatrix (bluefish), only estuarine resident and estuarine dependent species were found at Tramandaí (Table 3). Across all sites, the marine vagrant guild was represented by either a single species (Tramandaí, Chuí) or two species (Patos Lagoon). The estuarine resident Odonthestes argentinensis (silverside) and estuarine-dependent species C. sapidus (blue crab), Micropogonias furnieri (whitemouth croaker), and Mugil liza (mullet) were collected at all three sites (Table 3).

At the assemblage level, nitrogen isotopic signatures of consumers ranged from $\sim 6-16 \%$ (Fig. 2), 
Table 3 Fishes and invertebrates collected at each site, with ecological guild, size range, and mean ( \pm 1 SD) carbon and nitrogen isotope values

\begin{tabular}{|c|c|c|c|c|c|c|c|}
\hline Species & Guild & $n$ & Size class $(\mathrm{mm})$ & $\delta^{15} \mathrm{~N}$ & $\pm 1 \mathrm{SD}$ & $\delta^{13} \mathrm{C}$ & $\pm 1 \mathrm{SD}$ \\
\hline \multicolumn{8}{|l|}{ Tramandaí } \\
\hline Lycengraulis grossidens & ED & 3 & $90-96$ & 12.5 & & -19.0 & \\
\hline Micropogonias furnieri & ED & 2 & $87-98$ & 13.2 & 0.11 & -15.3 & 0.43 \\
\hline Micropogonias furnieri & $\mathrm{ED}$ & 3 & $127-128$ & 13.5 & 0.12 & -14.7 & 1.08 \\
\hline Mugil liza & ED & 8 & $27-34$ & 7.6 & & -20.0 & \\
\hline Mugil liza & ED & 3 & 99-101 & 9.1 & 1.21 & -13.5 & 2.26 \\
\hline Mugil liza & ED & 3 & $214-240$ & 9.3 & 0.53 & -15.4 & 3.18 \\
\hline Genidens barbus & $\mathrm{ED}$ & 3 & $319-357$ & 14.9 & 0.24 & -14.9 & 0.63 \\
\hline Atherinella brasiliensis & ER & $6^{*}$ & $83-129$ & 13.0 & 0.33 & -16.7 & 0.87 \\
\hline Odonthestes argentinensis & ER & 5 & $36-50$ & 12.3 & & -16.3 & \\
\hline Odonthestes argentinensis & ER & 3 & $153-155$ & 13.8 & 0.46 & -15.3 & 0.93 \\
\hline Odonthestes argentinensis & ER & 3 & $229-255$ & 12.8 & 0.09 & -16.2 & 0.37 \\
\hline Pomatomus saltatrix & MV & 3 & $146-176$ & 14.8 & 1.80 & -16.3 & 0.37 \\
\hline Callinectes sapidus & ED & 5 & $53-84$ & 13.1 & & -16.1 & \\
\hline Farfantepenaeus paulensis & $\mathrm{ED}$ & & & 9.9 & 0.21 & -11.4 & 0.53 \\
\hline Heteromastus similis & ER & & & 8.6 & & -18.0 & \\
\hline Laeonereis acuta & ER & & & 9.8 & & -14.3 & \\
\hline Nephtys fluviatilis & ER & & & 10.8 & & -14.8 & \\
\hline \multicolumn{8}{|l|}{ Patos Lagoon } \\
\hline Brevoortia pectinata & ED & 25 & $35-40$ & 9.5 & & -17.2 & \\
\hline Lycengraulis grossidens & ED & 1 & 85 & 11.0 & & -17.8 & \\
\hline Micropogonias furnieri & $\mathrm{ED}$ & $30 *$ & $48-100$ & 12.1 & 0.76 & -15.0 & 0.85 \\
\hline Micropogonias furnieri & $\mathrm{ED}$ & 9 & $120-179$ & 11.3 & 1.87 & -14.7 & 1.25 \\
\hline Micropogonias furnieri & $\mathrm{ED}$ & 3 & $211-223$ & 13.6 & 3.46 & -17.7 & 2.05 \\
\hline Mugil liza & $\mathrm{ED}$ & $21 *$ & $23-50$ & 8.4 & 0.36 & -16.1 & 2.90 \\
\hline Mugil liza & $\mathrm{ED}$ & 3 & $395-415$ & 9.2 & 1.11 & -15.2 & 1.20 \\
\hline Genidens barbus & $\mathrm{ED}$ & 4 & $88-100$ & 15.5 & & -15.3 & \\
\hline Genidens barbus & ED & $10 *$ & $102-153$ & 10.9 & 0.51 & -18.3 & 0.75 \\
\hline Paralichthys orbignyanus & $\mathrm{ED}$ & 2 & $98-106$ & 11.6 & & -12.4 & \\
\hline Catathyridium garmani & ER & 3 & $125-137$ & 11.0 & 0.60 & -14.8 & 1.36 \\
\hline Atherinella brasiliensis & ER & 2 & $94-96$ & 12.3 & & -14.6 & \\
\hline Genidens genidens & ER & 5 & $87-101$ & 12.0 & & -16.5 & \\
\hline Ctenogobius shufeldti & ER & 9 & $50-70$ & 9.6 & & -13.3 & \\
\hline Odonthestes argentinensis & ER & $35^{*}$ & $36-100$ & 10.1 & 0.45 & -17.2 & 0.85 \\
\hline Jenynsia multidentata & $\mathrm{ER}^{*}$ & 8 & $33-54$ & 8.1 & & -18.6 & \\
\hline Astyanax eigenmanniorum & $\mathrm{FV}$ & 11 & $35-47$ & 7.7 & & -23.9 & \\
\hline Astyanax sp. & FV & 6 & $56-67$ & 10.6 & & -18.7 & \\
\hline Hoplias aff. malabaricus & $\mathrm{FV}$ & 3 & $270-281$ & 10.8 & 0.35 & -22.0 & 0.21 \\
\hline Platanichthys platana & $\mathrm{FV}$ & 8 & $50-93$ & 11.1 & & -19.2 & \\
\hline Geophagus brasiliensis & $\mathrm{FV}^{*}$ & 3 & $104-113$ & 8.8 & 0.64 & -17.8 & 3.84 \\
\hline Geophagus brasiliensis & $\mathrm{FV}^{*}$ & 3 & $140-162$ & 11.1 & 1.13 & -16.3 & 2.03 \\
\hline Citharichthys spilopterus & MV & 1 & & 10.6 & & -15.2 & \\
\hline
\end{tabular}


Table 3 continued

\begin{tabular}{|c|c|c|c|c|c|c|c|}
\hline Species & Guild & $n$ & Size class $(\mathrm{mm})$ & $\delta^{15} \mathrm{~N}$ & $\pm 1 \mathrm{SD}$ & $\delta^{13} \mathrm{C}$ & $\pm 1 \mathrm{SD}$ \\
\hline Symphurus jenynsi & MV & $4 *$ & $51-104$ & 12.7 & 0.85 & -14.9 & 1.80 \\
\hline Callinectes sapidus & ED & $16^{*}$ & $36-145$ & 8.3 & 1.13 & -15.9 & 0.64 \\
\hline Farfantepenaeus paulensis & ED & 7 & $70-105$ & 9.0 & & -12.5 & \\
\hline Erodona mactroides & ER & 6 & $4-7$ & 5.7 & & -16.9 & \\
\hline Laeonereis acuta & ER & 2 & & 7.8 & 1.16 & -14.7 & 1.45 \\
\hline Nephtys fluviatilis & ER & 1 & & 10.1 & & -14.5 & \\
\hline \multicolumn{8}{|l|}{ Chuí } \\
\hline Micropogonias furnieri & ED & 4 & $82-93$ & 14.4 & & -16.3 & \\
\hline Mugil liza & ED & $21 *$ & $35-75$ & 9.4 & 1.04 & -16.6 & 0.27 \\
\hline Mugil liza & ED & $4 *$ & $205-254$ & 9.7 & 0.38 & -17.8 & 2.87 \\
\hline Paralichthys orbignyanus & ED & 1 & 146 & 12.0 & & -17.8 & \\
\hline Ctenogobius shufeldti & ER & 2 & $98-108$ & 9.4 & & -24.4 & \\
\hline Odonthestes argentinensis & ER & 4 & $54-60$ & 11.7 & & -25.5 & \\
\hline Odonthestes argentinensis & ER & 1 & 125 & 11.9 & & -25.1 & \\
\hline Jenynsia multidentata & $\mathrm{ER}^{*}$ & 15 & $21-56$ & 10.7 & & -22.3 & \\
\hline Astyanax jacuhiensis & $\mathrm{FV}$ & 5 & $64-76$ & 8.5 & & -24.7 & \\
\hline Astyanax fasciatus & $\mathrm{FV}$ & 3 & $55-75$ & 8.9 & & -29.2 & \\
\hline Astyanax fasciatus & FV & 2 & $137-156$ & 11.3 & & -28.3 & \\
\hline Charax stenopterus & $\mathrm{FV}$ & 3 & $72-85$ & 10.4 & & -27.7 & \\
\hline Crenicichla lepidota & $\mathrm{FV}$ & 2 & $115-188$ & 10.1 & 0.87 & -28.0 & 1.41 \\
\hline Crenicichla punctata & FV & 1 & 113 & 11.3 & & -26.7 & \\
\hline Cyphocharax voga & $\mathrm{FV}$ & 1 & 74 & 8.2 & & -24.0 & \\
\hline Hoplias aff. malabaricus & $\mathrm{FV}$ & 1 & 355 & 11.3 & & -25.7 & \\
\hline Oligosarcus robustus & $\mathrm{FV}$ & 1 & 72 & 10.8 & & -23.9 & \\
\hline Oligosarcus robustus & FV & 1 & 153 & 10.8 & & -25.4 & \\
\hline Pimelodella australis & $\mathrm{FV}$ & 3 & $79-87$ & 10.6 & & -27.5 & \\
\hline Platanichthys platana & FV & 1 & 84 & 12.5 & & -20.7 & \\
\hline Pseudocorynopoma doriae & $\mathrm{FV}$ & 4 & $69-81$ & 10.8 & & -25.6 & \\
\hline Rineloricaria longicauda & FV & 2 & $138-142$ & 10.8 & & -26.5 & \\
\hline Geophagus brasiliensis & $\mathrm{FV}^{*}$ & 3 & 84-104 & 9.2 & & -25.8 & \\
\hline Geophagus brasiliensis & $\mathrm{FV}^{*}$ & 1 & 218 & 7.2 & & -29.2 & \\
\hline Paralonchurus brasiliensis & MV & 2 & $99-124$ & 13.6 & & -18.6 & \\
\hline Callinectes sapidus & ED & $10 *$ & $40-100$ & 11.5 & 0.33 & -19.0 & 0.29 \\
\hline Cyrtograpsus angulatus & ER & 3 & $22-24$ & 12.0 & & -18.4 & \\
\hline Palaemonetes argentinus & $\mathrm{FV}^{*}$ & 4 & $52-59$ & 10.4 & & -25.1 & \\
\hline
\end{tabular}

$E D$ estuarine dependent, $E R$ estuarine resident, $E R^{*}$ freshwater species, but abundant in the estuary year-round, $M V$ marine vagrant, $F V$ freshwater vagrant, $F V^{*}$ freshwater species that is salinity tolerant, being frequently found in the estuary (second order freshwater fish). Blank lines within sites separate fish from invertebrate species. Species or size-classes with multiple individuals sampled but no standard deviations are composite samples (see "Materials and methods" section); sample sizes with an asterisk include one or more composite samples

and did not differ among sites $\left(F_{2,71}=2.68\right.$, $P=0.08)$. This range of variation in consumer nitrogen isotope ratios corresponds to approximately three to four trophic levels considering a trophic fractionation of between $+2.5 \%$ (Vanderklift \& Ponsard, 2003) and $+3.4 \%$ (Post, 2002). Consumer $\delta^{13} \mathrm{C}$ values differed significantly among sites $\left(F_{2,71}=52.38, P<0.001\right)$, and post-hoc analyses 
Fig. 2 Carbon and nitrogen isotope bi-plots of fish and macroinvertebrate consumers in Tramandaí, Patos Lagoon and Chuí estuaries. Bars represent ranges of $\delta^{13} \mathrm{C}$ for $\mathrm{C}_{3}$ macrophytes, $\mathrm{C}_{4}$ macrophytes and submerged aquatic vegetation (SAV). The arrow represents the range of $\delta^{13} \mathrm{C}$ for algae along a freshwater to marine salinity gradient (Fry, 2002). Filled symbols are fishes and open symbols are invertebrates. Ecological guilds and species codes: estuarine dependents (filled diamonds): 1, Brevoortia pectinata; 2, Callinectes sapidus; 3, Farfantepenaeus paulensis; 4, Lycengraulis grossidens; 5, Micropogonias furnieri; 6, Mugil liza; 7, Genidens barbus; 8, Paralichthys orbignyanus; estuarine residents (filled circle): 9, Catathyridium garmani; 10, Atherinella brasiliensis; 11, Cyrtograpsus angulatus; 12, Erodona mactroides; 13, Genidens genidens; 14, Ctenogobius shufeldti; 15, Heteromastus similis; 16, Jenynsia multidentata; 17, Laeonereis acuta; 18, Nephtys fluviatilis; 19, Odonthestes argentinensis; freshwater vagrants (filled triangles): 20, Astyanax bimaculatus; 21, Astyanax eigenmanniorum; 22, Astyanax fasciatus; 23, Astyanax sp.; 24, Charax stenopterus; 25, Crenicichla lepidota; 26, Crenicichla punctata; 27, Cyphocarax voga; 28, Geophagus brasiliensis; 29, Hoplias aff. malabaricus; 30, Oligosarcus robustus; 31, Palaemonetes argentinensis; 32, Pimelodella australis; 33, Platanychthys platana; 34, Pseudocorynopoma doriae; 35, Rineloricaria longicauda; marine vagrants (filled squares): 36, Citharichthys spilopterus; 37, Gobionellus oceanicus; 38, Paralonchurus brasiliensis; 39, Pomatomus saltatrix; 40, Symphurus jenynsi

distinguished the comparatively ${ }^{13} \mathrm{C}$ depleted freshwater vagrant-dominated assemblage at Chuí from the more ${ }^{13} \mathrm{C}$-enriched estuarine resident- and estuarine dependent-dominated assemblages at Patos Lagoon and Tramandaí (Fig. 2; Table 3). At both Patos Lagoon and Tramandaí, consumer $\delta^{13} \mathrm{C}$ values were mostly between -12 and $-20 \%$, whereas consumer $\delta^{13} \mathrm{C}$ values at Chuí ranged from $\sim-16$ to $-30 \%$ (Fig. 2; Table 3).

Even though the consumer assemblages of Patos Lagoon and Tramandaí were enriched in ${ }^{13} \mathrm{C}$ compared to Chuí, $\delta^{13} \mathrm{C}$ values of the freshwater vagrant guild were consistently more depleted than the other guilds within sites when present (Fig. 2; Table 3). At Patos, consumer $\delta^{13} \mathrm{C}$ values differed significantly among guilds $\left(F_{3,25}=6.35, P=0.002\right)$, and post-hoc analyses distinguished the relatively ${ }^{13} \mathrm{C}$-depleted freshwater vagrant guild from all three other guilds. Significant differences in consumer $\delta^{13} \mathrm{C}$ values were also observed among guilds at Chuí $\left(F_{3,24}=22.50, P<0.001\right)$, with the freshwater vagrant, estuarine dependent and estuarine resident guilds all significantly different in post-hoc analyses. Freshwater vagrants were the most depleted in ${ }^{13} \mathrm{C}$, estuarine residents had intermediate values, and estuarine-dependent species were relatively enriched in ${ }^{13} \mathrm{C}$ (Fig. 2). No difference in $\delta^{13} \mathrm{C}$ values was observed
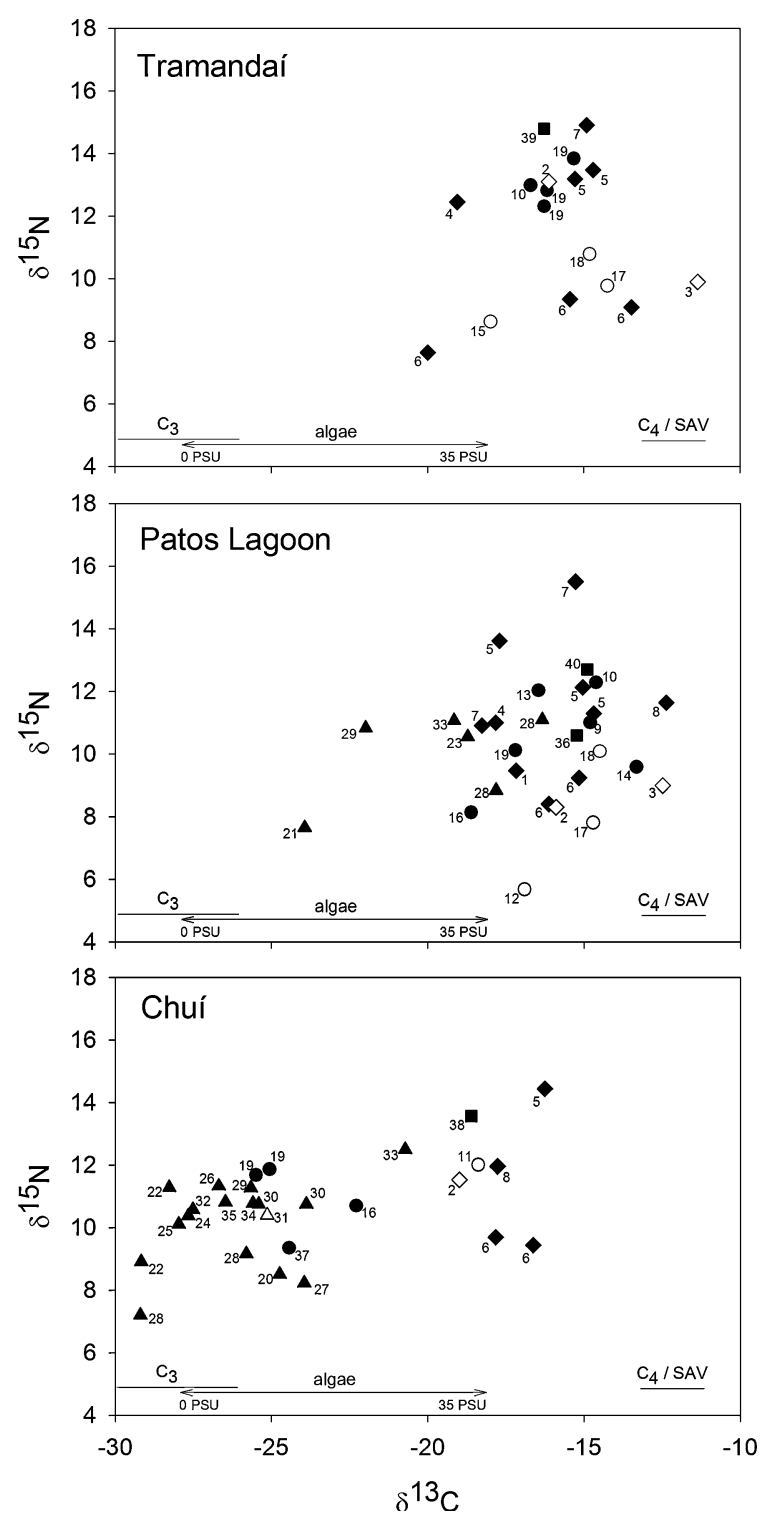

among guilds at Tramandaí $\left(F_{2,14}=0.08, P=0.925\right)$, where species in the freshwater vagrant guild were not present.

The four species collected at all three sites exhibited different patterns in their $\delta^{13} \mathrm{C}$ values. Carbon isotopic signatures of the estuarine-dependent species $C$. sapidus, M. furnieri, and M. liza differed little among sites, although at Tramandaí the smallest size class of mullet $M$. liza was depleted more than $4 \%$ compared to the two larger size classes sampled, and $C$. sapidus at Chuí were slightly depleted in ${ }^{13} \mathrm{C}$ compared to the other sites (Table 3 ). The silverside $O$. argentinensis, an estuarine-resident species, had similar $\delta^{13} \mathrm{C}$ values at Tramandaí and Patos (approximately -16 and $-17 \%$, 
respectively), but both size classes collected at Chuí were $\sim 8 \%$ more depleted $(-25 \%$, Table 3$)$.

\section{Discussion}

Estuary hydrogeomorphology and communitylevel variation in isotope signatures

The three subtropical estuaries examined in this study were broadly classified based on landscape-scale hydrogeomorphological characteristics as choked lagoons (Patos Lagoon, Tramandaí) and a coastal river (Chuí). The primary characteristics that distinguish these classifications are the total area of the mixohaline zone, size of the mixohaline zone relative to adjacent freshwater zones, cross-sectional elevation profile, and the relative proportion of open water habitat. These hydrogeomorphological differences affected the composition and relative abundances of primary producers (Isacch et al., 2006). For example, typical saltmarsh vegetation such as Spartina spp. occupied much greater areas in both choked lagoon estuaries compared with Chuí (Fig. 1; Table 2) because these lagoons have a greater proportion of lower elevation littoral and larger mixohaline zones. Widgeon grass ( $R$. maritima) also can form extensive meadows in the open water zones of choked lagoons during spring and summer, and macroalgae (Enteromorpha spp.) are common or abundant. In contrast, littoral vegetation at Chuí was dominated by $S$. olneyi and $J$. acutus, and the total area covered was lower because of steeper littoral elevation profiles.

These differences in primary producer composition and relative abundance are well represented by stable isotope ratios of carbon, because Spartina spp., $R$. maritima and Enteromorpha spp. are $\mathrm{C}_{4}$ plants ( $\delta^{13} \mathrm{C}$ between $-13 \%$ and $-10 \%$ ), whereas Juncus spp. and $S$. olneyi are $\mathrm{C}_{3}$ plants $\left(\delta^{13} \mathrm{C}\right.$ between $-29 \%$ o and $-26 \%$; Table 2). Phytoplankton also typically vary in $\delta^{13} \mathrm{C}$ along salinity gradients because of differences in carbon isotope signatures of dissolved inorganic carbon (DIC), becoming more depleted as the relative contribution of DIC of freshwater origin increases (Peterson et al., 1994; Canuel et al., 1995; Bouillon et al., 2000; Fry, 2002; Kaldy et al., 2005). Therefore, the relative area of mixohaline versus surrounding freshwater zones may affect the carbon isotope signature of algae being utilized by consumers, following the same trend of more enriched values in the choked lagoons.

Carbon isotope signatures of consumers across all three estuaries appear to reflect the consumption of local sources of primary production. As described above, the dominant primary producers at Chuí are considerably ${ }^{13} \mathrm{C}$-depleted compared with those from the two choked lagoon estuaries (i.e., $\mathrm{C}_{3}$ sources and depleted algae at Chuí, and $\mathrm{C}_{4}$ sources and enriched algae in the choked lagoons). This comparatively ${ }^{13} \mathrm{C}$-depleted resource base was reflected in tissues of consumers at the assemblage level (i.e., regardless of ecological guild). Carbon isotope ratios of consumers at Chuí were significantly depleted $\left(\delta^{13} \mathrm{C}\right.$ range of 30 to $-16 \%$ ) compared with the consumer assemblages of Patos Lagoon and Tramandaí $\left(\delta^{13} \mathrm{C}\right.$ range of -20 to $-12 \%$ ). Winemiller et al. (in press) observed a shift from $\mathrm{C}_{3}$-dependent food webs along the fluvial gradient to the $\mathrm{C}_{4}$-based food web of the seagrass/mangrove zone for a coastal river in Belize. A similar trend was observed by Garcia et al. (2007) along a gradient within Patos Lagoon, where consumers in estuarine zones appear to assimilate greater amounts of carbon from $\mathrm{C}_{4}$ production sources (e.g., Spartina spp., widgeon grass) and enriched benthic algae compared with upper freshwater reaches of the lagoon that are dominated by $\mathrm{C}_{3}$ production sources (e.g., Scirpus californicus, floating aquatic macrophytes such as Eichhornia spp.) and algae with depleted $\delta^{13} \mathrm{C}$. Comparable spatial variation in the relative importance of carbon sources to consumers within estuaries has been repeatedly observed among diverse temperate, subtropical and tropical estuaries (e.g., Peterson et al., 1985; Deegan \& Garritt, 1997; Chanton \& Lewis, 2002; Hsieh et al., 2002; Richoux \& Froneman, 2007, but see also Rodriguez-Grana et al., 2008).

Consumer isotope signatures among ecological guilds

Even though differences in isotope signatures of locally dominant primary production sources may account for the broad differences observed in $\delta^{13} \mathrm{C}$ of consumers at the assemblage level, we also observed significant differences in $\delta^{13} \mathrm{C}$ among ecological guilds within Patos Lagoon and Chuí estuaries. These within-site differences among ecological guilds may be attributed to movement and residence patterns in 
addition to relative abundances of different autotrophic resources (e.g., Herzka, 2005). For example, freshwater vagrant species collected in Patos Lagoon estuary were significantly depleted in ${ }^{13} \mathrm{C}$ compared with the other ecological guilds present. However, these individuals were enriched in ${ }^{13} \mathrm{C}$ compared with freshwater vagrant species collected in freshwater zones of this same lagoon where they naturally occur (Garcia et al., 2007) as well as freshwater vagrant species collected at Chuí. This suggests that the freshwater vagrant species collected in Patos Lagoon estuary colonized the area from upper freshwater reaches of the lagoon, but were present in the estuary long enough to have assimilated local ${ }^{13} \mathrm{C}$-enriched carbon sources, resulting in an intermediate carbon isotope signature.

In addition to freshwater vagrant species being more ${ }^{13} \mathrm{C}$ depleted than other ecological guilds at Chuí (having an almost completely "freshwater" signature), estuarine-dependent and estuarine-resident species also differed in their carbon isotope signatures. Estuarine-dependent species had the most enriched signatures and were only very slightly ${ }^{13} \mathrm{C}$ depleted compared with the same ecological guild at Patos and Tramandaí lagoons. These species (C. sapidus, M. furnieri, M. liza, Paralichthys orbignyanus) appeared to have retained an isotopic signature characteristic of choked lagoons, perhaps due to recent colonization of Chuí following movement from other nearby estuaries, such as Patos Lagoon, for reproduction in the adjacent marine environment. It is unlikely that the enriched signatures observed for these species are due to selectively feeding on less abundant $\mathrm{C}_{4}$ production sources because their diets can be characterized as omnivorous or detritivorous. Unlike the estuarine-dependent species that move offshore for spawning, estuarine resident species complete their entire life cycle in the estuary and had carbon isotope signatures only slightly less depleted than freshwater vagrant species collected at Chuí, but significantly depleted compared with estuarine dependent species. In choked lagoons, estuarine resident, and estuarine-dependent species did not differ in their isotopic signatures. At Chuí, estuarine resident species, therefore, appear to be assimilating local autotrophic sources, which happened to have depleted carbon isotope signatures. Evidence from tropical estuaries of eastern Australia indicates that the area (patch size) of saltmarsh vegetation affects the relative importance of that source to consumers within those patches (Guest \& Connolly, 2006). Therefore, the limited patch size of $\mathrm{C}_{4}$ saltmarsh vegetation at Chuí (due to a comparatively small mixohaline zone and steep littoral) could preclude the importance of this source even for species that occur most frequently in association with littoral vegetation zones where $\mathrm{C}_{4}$ saltmarsh plants may be present. The slight difference in freshwater vagrant and estuarine resident species at Chuí may be due to frequent movement of freshwater vagrant species between purely freshwater reaches and the estuarine zone.

Hydrogeomorphology and the relative importance of carbon sources supporting secondary production

Estuaries are dynamic mixing zones where potential autotrophic sources supporting secondary production could derive from in situ, freshwater or marine origin. The relative importance of diverse production sources to estuarine consumers may be influenced by multiple factors, including hydrogeomorphologic features that affect the relative size of the estuarine zone, patterns of freshwater inflow, type of connection with the marine ecosystem, and slope/extent of the littoral zone relative to open water. As discussed above, studies conducted across fluvial/salinity gradients within estuaries have found patterns similar to our findings comparing across three estuaries that differed in hydrogeomorphology. But can hydrogeomorphic factors identified at the landscape scale be useful for making generalizations or predictions regarding the relative importance of autotrophic carbon sources supporting secondary production of estuarine consumers?

Detecting patterns of resource utilization using stable isotopes requires isotopic differentiation of autotrophic sources (e.g., $\mathrm{C}_{3}$ and $\mathrm{C}_{4}$ vegetation, relationship between salinity and algal $\delta^{13} \mathrm{C}$ ). This appears highly feasible for most estuarine ecosystems, especially when including analyses of sulfur isotopes (e.g., Connolly et al., 2004). Although consumers in estuarine food webs typically rely on multiple resource pathways and functional groups may differ in their resource use (e.g., Alfaro et al., 2006), predictions may be made regarding dominant energy sources supporting consumers at the level of the entire assemblage. For example, carbon derived from $\mathrm{C}_{4}$ marsh grasses, such 
as Spartina spp. may be expected to be a major contributor to secondary production in those estuaries having expansive littoral zones and high densities of saltmarsh vegetation relative to open water area (e.g., Richoux \& Froneman, 2007; Winemiller et al., 2007). In contrast, secondary production in estuaries characterized by expansive open water zones relative to littoral area may depend on large contributions from various algal sources and submerged aquatic vegetation (e.g., Kang et al., 2003; Riera \& Hubas, 2003; Garcia et al., 2007). Similar to our data from Chuí, secondary production in coastal river estuaries with high freshwater inflow may rely on $\mathrm{C}_{3}$ productions sources, including ${ }^{13} \mathrm{C}$-depleted algae (e.g., Chanton \& Lewis, 2002).

Several studies have found that estuarine consumers often rely most heavily on locally abundant autotrophic sources produced in situ (e.g., Wainright et al., 2000, and the above cited references). Therefore, hydrogeomorphic factors that determine the relative abundance of such sources may also correlate with resource use by consumers. Although within-estuary variation is to be expected, estuaries may be broadly classified according to landscape-scale hydrogeomorphic factors (e.g., choked lagoon and coastal river as in this study) that allow an initial prediction of the relative importance of carbon sources to secondary production. Similar to our analyses of ecological guilds, predictions may be refined at the species level using ecological knowledge such as habitat use, ecomorphology and residence time. Such predictions are useful as a starting point for poorly studied regions such as ours, as well as for global-scale analyses of patterns in estuarine food webs. Future studies should directly measure aspects of hydrologic variation and geomorphology across a range of estuaries to test our generalizations and identify specific relationships and causal mechanisms. Continuing research should address interacting effects of latitude, seasonality/climatic factors, tidal amplitude, biogeography, functional composition of the consumer assemblage, and degree of movement of organisms among freshwater, estuarine, and marine environments.

Acknowledgments Thanks to the numerous colleagues and technicians that assisted in the field and laboratory work, especially A. C. Mai, F. Roselet and V. Condini. D.J.H. was supported in part by research scholarships from the Society of Wetland Scientists during field collection. A.M.G. acknowledges fellowship support provided by CNPq (Grant
150868/2003-0). K.O.W. and D.J.H. acknowledge financial support from the International Sportfish Fund.

\section{References}

Abreu, P. A., A. M. Anésio, C. Costa, C. Bemvenuti, C. Odebrecht \& W. Granéli, 2006. Eutrophication processes and trophic interactions in a shallow estuary: preliminary results based on stable isotope analysis $\left(\delta^{13} \mathrm{C}\right.$ and $\left.\delta^{15} \mathrm{~N}\right)$. Estuaries 29: 277-285.

Alfaro, A. C., F. Thomas, L. Sergent \& M. Duxbury, 2006. Identification of trophic interactions within an estuarine food web (northern New Zealand) using fatty acid biomarkers and stable isotopes. Estuarine, Coastal and Shelf Science 70: 271-286.

Bardonnet, A. \& P. Riera, 2005. Feeding of glass eels (Anguilla anguilla) in the course of their estuarine migration: new insights from stable isotope analysis. Estuarine Coastal and Shelf Science 63: 201-209.

Bouillon, S., P. Chandra Mohan, N. Sreenivas \& F. Dehairs, 2000. Sources of suspended organic matter and selective feeding by zooplankton in an estuarine mangrove ecosystem as traced by stable isotopes. Marine Ecology Progress Series 208: 79-92.

Camara, G., R. C. M. Souza, U. M. Freitas \& J. Garrido, 1996. SPRING: integrating remote sensing and GIS by objectoriented data modelling. Computer \& Graphics 20: 395-403.

Canuel, E. A., J. E. Cloern, D. B. Ringelberg, J. B. Guckert \& G. H. Rau, 1995. Molecular and isotopic tracers used to examine sources of organic matter and its incorporation into the food webs of San Francisco Bay. Limnology and Oceanography 40: 67-81.

Chanton, J. \& F. G. Lewis, 2002. Examination of coupling between primary and secondary production in a riverdominated estuary: Apalachicola Bay, Florida. U.S.A. Limnology and Oceanography 47: 683-697.

Connolly, R. M., M. A. Guest, A. J. Melville \& J. M. Oakes, 2004. Sulfur stable isotopes separate producers in marine food-web analysis. Oecologia 138: 161-167.

Connolly, R. M., D. Gorman \& M. A. Guest, 2005. Movement of carbon among estuarine habitats and its assimilation by invertebrates. Oecologia 144: 684-691.

Costa, C. S. B., U. Seeliger, C. P. L. Oliveira \& A. M. M. Mazo, 1997. Distribuição, funções e valores das marismas e pradarias submersas no estuário da Lagoa dos Patos (RS, Brasil). Atlântica 19: 65-83.

Day, J. W., C. A. S. Hall, W. M. Kemp \& A. Yanez-Arancibia, 1989. Estuarine Ecology. Wiley, New York.

Deegan, L. A., 1993. Nutrient and energy transport between estuaries and coastal marine ecosystems by fish migration. Canadian Journal of Fisheries and Aquatic Sciences 50: 74-79.

Deegan, L. A. \& R. H. Garritt, 1997. Evidence for spatial variability in estuarine food webs. Marine Ecology Progress Series 147: 31-47.

Fry, B., 2002. Conservative mixing of stable isotopes across estuarine salinity gradients: a conceptual framework for 
monitoring watershed influences on downstream fisheries production. Estuaries 25: 264-271.

Garcia, A. M. \& J. P. Vieira, 1997. Abundância e diversidade da assembléia de peixes dentro e fora de uma pradaria de Ruppia maritima L., no estuário da Lagoa dos Patos (RSBrasil). Atlântica 19: 161-181.

Garcia, A. M., J. P. Vieira, C. E. Bemvenuti \& R. M. Geraldi, 1996. Abundância e diversidade da assembléia de crustáceos decápodes dentro e fora de uma pradaria de Ruppia maritima L., no estuário da Lagoa dos Patos (RS-Brasil). Náuplius 4: 113-128.

Garcia, A. M., J. P. Vieira \& K. O. Winemiller, 2003. Effects of 1997-1998 El Niño on the dynamics of the shallowwater fish assemblage of the Patos Lagoon estuary (Brazil). Estuarine Coastal and Shelf Science 57: 489-500.

Garcia, A. M., J. P. Vieira, K. O. Winemiller \& A. M. Grimm, 2004. Comparison of the 1982-1983 and 1997-1998 El Nino effects on the shallow-water fish assemblage of the Patos Lagoon estuary (Brazil). Estuaries 27: 905-914.

Garcia, A. M., D. J. Hoeinghaus, J. P. Vieira \& K. O. Winemiller, 2007. Isotopic variation of fishes in freshwater and estuarine zones of a large subtropical coastal lagoon. Estuarine Coastal and Shelf Science 73: 399-408.

Garman, G. C. \& S. A. Macko, 1998. Contribution of marinederived organic matter to an Atlantic coast, freshwater, tidal stream by anadromous clupeid fish. Journal of the North American Benthological Society 17: 277-285.

Gauch, H. G. Jr., 1984. Multivariate Analysis in Community Ecology. Cambridge University Press, Cambridge.

Guest, M. A. \& R. M. Connolly, 2006. Movement of carbon among estuarine habitats: the influence of saltmarsh patch size. Marine Ecology Progress Series 310: 15-24.

Herzka, S. Z., 2005. Assessing connectivity of estuarine fishes based on stable isotope ratio analysis. Estuarine, Coastal and Shelf Science 64: 58-69.

Hoeinghaus, D. J. \& S. E. Davis III, 2007. Size-based trophic shifts of salt-marsh dwelling blue crabs elucidated by dual stable $\mathrm{C}$ and $\mathrm{N}$ isotope analyses. Marine Ecology Progress Series 334: 199-204.

Hoeinghaus, D. J., K. O. Winemiller \& A. A. Agostinho, 2007. Landscape-scale hydrologic characteristics differentiate patterns of carbon flow in large-river food webs. Ecosystems 10: 1019-1033.

Hoeinghaus, D. J., K. O. Winemiller \& A. A. Agostinho, 2008. Hydrogeomorphology and river impoundment affect food-chain length of diverse neotropical food webs. Oikos 117: 984-995.

Hsieh, H. L., C. P. Chen, Y. G. Chen \& H. H. Yang, 2002. Diversity of benthic organic matter flows through polychaetes and crabs in a mangrove estuary: $\delta^{13} \mathrm{C}$ and $\delta^{34} \mathrm{~S}$ signals. Marine Ecology Progress Series 227: 145-155.

Isacch, J. P., C. S. B. Costa, L. Rodríguez-Gallego, D. Conde, M. Escapa, D. A. Gagliardini \& O. O. Iribarne, 2006. Distribution of saltmarsh plat communities associated with environmental factors along a latitudinal gradient on the south-west Atlantic coast. Journal of Biogeography 33: 888-900.

Kaldy, J. E., L. A. Cifuentes \& D. Brock, 2005. Using stable isotope analyses to assess carbon dynamics in a shallow subtropical estuary. Estuaries 28: 86-95.
Kanaya, G., S. Takagi, E. Nobata \& E. Kikuchi, 2007. Spatial dietary shift of macrozoobenthos in a brackish lagoon revealed by carbon and nitrogen stable isotope ratios. Marine Ecology Progress Series 345: 117-127.

Kang, C. K., J. B. Kim, K. S. Lee, J. B. Kim, P. Y. Lee \& J. S. Hong, 2003. Trophic importance of benthic microalgae to macrozoobenthos in coastal bay systems in Korea: dual stable $\mathrm{C}$ and $\mathrm{N}$ isotope analyses. Marine Ecology Progress Series 259: 79-92.

Kennish, M. J., 1990. Ecology of Estuaries, Vol. 1. Physical and Chemical Aspects. CRC Press, Boca Raton.

Kjerfve, B., 1986. Comparative oceanography of coastal lagoons. In Wolfe, D. A. (ed.), Estuarine Variability. Academic Press, Orlando: 63-81.

MacAvoy, S. E., S. A. Macko, S. P. McIninch \& G. C. Garman, 2000. Marine nutrient contributions to freshwater apex predators. Oecologia 122: 568-573.

Moller, O. O. J., P. Casting, J.-C. Salomon \& P. Lazure, 2001. The influence of local and non-local forcing effects on the subtidal circulation of Patos Lagoon. Estuaries 24: 297-311.

Pereira, L. E., L. A. Ramos \& S. X. Pontes, 1998. Lista comentada dos peixes e crustáceos decápodas do estuário do Arroio Chuí e região costeira adjacente, RS. Atlântica 20: 165-172.

Peterson, B. J. \& B. Fry, 1987. Stable isotopes in ecosystem studies. Annual Review of Ecology and Systematics 18: 293-320.

Peterson, B. J., R. W. Howarth \& R. H. Garritt, 1985. Multiple stable isotopes used to trace the flow of organic matter in estuarine food webs. Science 227: 1361-1363.

Peterson, B. J., B. Fry, M. A. Hullar, S. Saupe \& R. Wright, 1994. The distribution and stable carbon isotopic composition of dissolved organic carbon in estuaries. Estuaries 17: 111-121.

Post, D. M., 2002. Using stable isotopes to estimate trophic position: models, methods and assumptions. Ecology 83: 703-718.

Reis, E. G. \& F. D'incao, 2000. The present status of artisanal fisheries of extreme Southern Brazil: an effort towards community-based management. Ocean \& Coastal Management 43: 585-595.

Richoux, N. B. \& P. W. Froneman, 2007. Assessment of spatial variation in carbon utilization by benthic and pelagic invertebrates in a temperate South African estuary using stable isotope signatures. Estuarine Coastal and Shelf Science 71: 545-558.

Riera, P. \& C. Hubas, 2003. Trophic ecology of nematodes from various microhabitats of the Roscoff Aber Bay (France): importance of stranded macroalgae evidenced through delta C-13 and delta N-15. Marine Ecology Progress Series 260: 151-159.

Rodriguez-Grana, L., D. Calliari, D. Conde, J. Sellanes \& R. Urrutia, 2008. Food web of a SW Atlantic shallow coastal lagoon: spatial environmental variability does not impose substantial changes in the trophic structure. Marine Ecology Progress Series 362: 69-83.

Rosa-Filho, J. S., C. E. Bemvenuti \& M. Elliott, 2004. Predicting biological parameters of estuarine benthic communities using models based on environmental data. Brazilian Archives of Biology and Technology 47: 613-627. 
Rubenstein, D. R. \& K. A. Hobson, 2004. From birds to butterflies: animal movement patterns and stable isotopes. Trends in Ecology and Evolution 19: 256-263.

Schwarzbold, A. \& A. Schäfer, 1984. Gênese e morfologia das lagoas costeiras do Rio Grande do Sul, Brasil. Amazoniana 9: 87-104.

Seeliger, U., 2001. The Patos Lagoon Estuary, Brazil. In Seeliger, U. \& B. Kjerfve (eds), Coastal Marine Ecosystems of Latin America. Springer Verlag, Berlin: 167-182.

Seeliger, U., C. Odebrecht \& J. P. Castello, 1996. Subtropical Convergence Environments: The Coast and Sea in the Southwestern Atlantic. Springer Verlag, Berlin.

Vanderklift, M. A. \& S. Ponsard, 2003. Sources of variation in consumer-diet d $15 \mathrm{~N}$ enrichment: a meta-analysis. Oecologia 136: 169-182.

Vieira, J. P. \& J. P. Castello, 1996. Fish fauna. In Seeliger, U., C. Odebrecht \& J. P. Castello (eds), Subtropical Convergence Environments: The Coast and Sea in the Southwestern Atlantic. Springer Verlag, Berlin: 56-61.
Wainright, S. C., M. P. Weinstein, K. W. Able \& C. A. Currin, 2000. Relative importance of benthic microalgae, phytoplankton and the detritus of smooth cordgrass Spartina alterniflora and the common reed Phragmites australis to brackish-marsh food webs. Marine Ecology Progress Series 200: 77-91.

Winemiller, K. O., S. Akin \& S. C. Zeug, 2007. Production sources and food web structure of a temperate tidal estuary: integration of dietary and stable isotope data. Marine Ecology Progress Series 343: 63-76.

Winemiller, K. O., D. J. Hoeinghaus, A. A. Pease, P. E. Esselman, R. L. Honeycutt, D. Gbanaador, E. Carrera \& J. Payne, in press. Stable isotope analysis reveals food web structure and watershed impacts along the fluvial gradient of a Mesoamerican coastal river. River Research and Applications. 